\title{
PENGARUH KONFLIK PERAN GANDA DAN STRES KERJA TERHADAP KINERJA POLISI WANITA DI POLRESTA PADANG
}

\author{
Nur Ismiati, Zusmawati \\ STIE “KBP” Padang \\ nurismiati_mia@yahoo.co.id
}

\begin{abstract}
This study aims to determine the effect of dual role conflict and work stress on Police performance in Police Padang, independent variables of this research are dual role conflict and work stress, while the dependent variable is the performance of female police. The population used in this research is married female police, the sample of this research are 63 respondents and the technique used is Pusposive Sampling (sampling based on Criteria or certain conditions). The analysis used in this research includes validity test, reliability test, classic assumption test, multicollinearity test, heterokedasticity test, multiple linear regression analysis, determination coefficient, hypothesis testing which includes $t$ test, $F$ test, and determination coefficient (R2). Partially indicates that dual role conflict has no significant effect on the performance of female police officers. While work stress has a significant positive effect on the performance of female police. Therefore, to improve the performance of women police work stress needs to be managed optimally by providing appropriate workload.
\end{abstract}

Keywords: Multiple Role Conflicts, Job Stress and Performance

\section{PENDAHULUAN}

Pengelolaan sumber daya manusia (SDM) merupakan hal yang penting dalam hal pencapaian tujuan. Umumnya pimpinan perusahaan mengharapkan kinerja yang baik dari masing-masing karyawan dalam mengerjakan tugas-tugas yang diberikan perusahaan. Perusahaan menyadari bahwa sumber daya manusia (SDM) merupakan modal dasar dalam proses pembangunan perusahaan bahkan nasional, oleh karena itu kualitas SDM senantiasa harus dikembangkan dan diarahkan agar tercapainya tujuan yang telah ditetapkan oleh perusahaan. Tanpa peran manusia meskipun berbagai faktor yang dibutuhkan itu telah tersedia, organisasi tidak akan berjalan. Karena manusia merupakan penggerak dan penentu jalannya suatu organisasi. Oleh karena itu hendaknya organisasi memberikan arahan yang positif demi tercapainya tujuan organisasi.

Kinerja pada umumnya diartikan sebagai kesuksesan seseorang dalam melaksanakan suatu pekerjaan. Karyawan dapat bekerja dengan baik bila memiliki kinerja yang tinggi sehingga dapat menghasilkan kerja yang baik. Kinerja karyawan merupakan salah satu faktor penentu keberhasilan perusahaan atau organisasi dalam 
mencapai tujuannya. Untuk itu kinerja dari para karyawan harus mendapat perhatian dari para pimpinan perusahaan, sebab menurunnya kinerja dari karyawan dapat mempengaruhi kinerja perusahaan secara keseluruhan.

Organisasi atau instansi yang bergerak di bidang keamanan negara adalah Kepolisian Negara Republik Indonesia, Kepolisian Negara Republik Indonesia berada di bawah Presiden dan dipimpin oleh Kapolri yang dalam pelaksanaan tugasnya bertanggung jawab kepada Presiden sesuai dengan peraturan perundang-undangan. Kepolisian Negara Republik Indonesia yang memiliki peran penting di dalam masyarakat karena tugas-tugas pokoknya yang dapat menciptakan suatu kestabilan nasional yaitu sebagai pembimbing, pengayom, dan pelayan masyarakat. Hal ini tercantum dalam Pasal 13 Undang-Undang Nomor 2 Tahun 2002 tentang Kepolisian Negara Republik Indonesia yang dimuat dalam Lembaran Negara Nomor 2 tahun 2002. Tugas pokok kepolisian Negara Republik Indonesia: a. Memelihara keamanan dan ketertiban masyarakat. b. Menegakkan hukum dan c. Memberikan perlindungan, pengayoman, dan pelayanan kepada masyarakat.

Melihat dengan tuntutan dan kewajiban yang harus dijalani oleh wanita karir yaitu polisi wanita, maka tidak sedikit yang akan mengalami susahnya menyeimbangkan antara dua peran tersebut. Pihak keluarga yang merasa tidak nyaman karena sebagaian besar waktu dihabiskan di kantor, terkadang menuntut untuk meluangkan waktu bersama keluarga. Hal ini adalah salah satu pemicu timbulnya stres yang akan berpengaruh pada kinerja seorang polwan.

Ketika polisi wanita memiliki kinerja yang baik maka akan menghasilkan suatu kepuasan dalam bekerja, tetapi ketika tidak mendapatkan dalam kepuasan kerja maka polisi wanita akan lebih sering izin meninggalkan tugas, cuti bahkan membolos saat bekerja sehingga dalam hal ini akan mempengaruhi kinerja organisasi kepolisian (Gitoyo, 2012).

Berdasarkan uraian diatas, maka penulis tertarik untuk mengangkat judul "Pengaruh Konflik Peran Ganda Dan Stres Kerja Terhadap Kinerja Polisi Wanita Di Polresta Padang."

\section{LANDASAN TEORI DAN HIPOTESIS \\ Kinerja}

Kinerja karyawan adalah hasil kerja yang dicapai seseorang atau kelompok orang sesuai dengan wewenang atau tanggung jawab masing- masing karyawan selama periode tertentu (Pabunda Tika. 2006: 121). Sebuah perusahaan perlu melakukan penilaian kinerja pada karyawannya. Penilaian kinerja memainkan peranan yang sangat penting dalam peningkatan motivasi di tempat kerja.

Indikator kinerja menurut Robert dan John (2006: 378) dalam (Ginanjar 2013) mengatakan bahwa kinerja pada dasarnya adalah apa yang dilakukan dan tidak dilakukan karyawan, indikikator kinerja antara lain sebagai berikut :

1. Kuantitas dari hasil, yaitu jumlah yang harus diselesaikan atau dicapai berkaitan dengan jumlah keluaran yang dihasilkan.

2. Kualitas dari hasil, yaitu mutu yang harus dihasilkan (baik tidaknya), pengukuran kualitatif keluaran mencerminkan pengukuran tingkat kepuasan, yaitu seberapa baik penyelesainnya. Ini berkaitan dengan bentuk keluaran. 
3. Ketepatan waktu dari hasil, yaitu sesuai tidaknya dengan waktu yang direncanakan. Pengukuran ketepatan waktu merupakan jenis khusus dari pengukuran kuantitatif yang menentukan ketepatan waktu penyelesaian suatu kegiatan.

4. Kehadiran, yaitu ada tidaknya karyawan didalam kantor ketika memasuki jamjam kerja

5. Kemampuan bekerja sama, yaitu kemampuan karyawan melakukan kegiatan bersama-sama dengan karyawan lain dalam suatu kegiatan yang tidak dapat dikerjakan oleh perorangan.

\section{Penilaian Kinerja}

Handoko (1993) dalam (Iqbal 2016) menyatakan bahwa untuk dapat menilai kinerja seseorang digunakan dua buah konsepsi utama, yaitu efisiensi dan efektivitas. Efisiensi adalah kemampuan untuk menyelesaikan sesuatu pekerjaan dengan benar. Efektivitas adalah kemampuan untuk memilih tujuan yang tepat, untuk mencapai tujuan yang telah ditetapkan. Evaluasi kerja adalah kegiatan penentuan sampai pada tingkat dimana seseorang melakukan tugasnya secara efektif.

Pengukuran kinerja juga dapat dilakukan melalui beberapa penilaian (Flippo, 1986), antara lain :

1. Kualitas kerja, merupakan tingkat dimana hasil akhir yang dicapai mendekati sempurna dalam arti memenuhi tujuan yang diharapkan oleh perusahaan/organisasi.

2. Kuantitas kerja, merupakan jumlah yang dihasilkan yang dinyatakan dalam istilah sejumlah unit kerja ataupun merupakan jumlah siklus aktivitas yang dihasilkan

3. Ketepatan waktu, merupakan tingkat aktivitas di selesaikannya pekerjaan tersebut pada waktu awal yang di inginkan.

4. Sikap, merupakan hal-hal yang berkaitan dengan sikap yang menunjukkan seberapa jauh tanggung jawab terhadap pelaksanaan pekerjaan, serta tingkat kemampuan seseorang untuk bekerja sama dengan orang lain dalam menyelesaikan tugas-tugasnya.

5. Efektifitas, tingkat pengetahuan sumber daya organisasi dimana dengan maksud menaikkan keuangan.

\section{Konflik Peran Ganda}

Greenhaus dan Beutell (1985) dalam (Silalahi 2015), konflik peran ganda (workfamily conflict) merupakan suatu konflik peran dalam diri individu yang muncul karena adanya tekanan peran dari pekerjaan yang bertentangan dengan peran keluarga, sehingga kedua peran tersebut secara mutual tidak dapat disejajarkan. Konflik peran memiliki dua bentuk, yaitu konflik pekerjaan-keluarga serta konflik keluarga-pekerjaan (Yavas et al., 2008).

Konflik peran ganda muncul antara harapan dari dua peran yang berbeda yang dimiliki oleh seseorang. Di pekerjaan, seorang wanita yang professional diharapkan untuk agresif, kompetitif, dan dapat menjalankan komitmennya pada pekerjaan. Di rumah, wanita sering kali diharapkan untuk merawat anak, menyayangi dan menjaga suaminya 


\section{Dimensi-dimensi Konflik Peran Ganda}

Menurut David (2003:13) dalam (Wirakristama 2011), konflik peran ganda bersifat bi-directional dan multidimensi. Bi-directional terdiri dari:

a. work-family conflict yaitu konflik yang muncul dikarenakan tanggung jawab pekerjaan yang mengganggu tanggung jawab terhadap keluarga.

b. family-work conflict yaitu konflik yang muncul dikarenakan tanggung jawab terhadap keluarga mengganggu tanggung jawab terhadap pekerjaan. Multidimensi dari konflik peran ganda muncul dari masing-masing direction dimana antara keduanya baik itu work-family conflict maupun family-work conflict masing-masing memiliki tiga dimensi yaitu:

a) time-based conflict, yaitu konflik yang terjadi karena waktu yang digunakan untuk memenuhi satu peran tidak dapat digunakan untuk memenuhi peran lainnya artinya pada saat yang bersamaan seseorang yang mengalami konflik peran ganda tidak akan bisa melakukan dua atau lebih peran sekaligus.

b) strain-based conflict, yaitu ketegangan yang dihasilkan oleh salah satu peran membuat seseorang sulit untuk memenuhi tuntutan perannya yang lain.

c) behavior-based conflict, yaitu konflik yang muncul ketika pengharapan dari suatu perilaku yang berbeda dengan pengharapan dari perilaku peran lainnya

\section{Faktor-faktor yang mempengaruhi konfik peran ganda}

Bellavia \& Frone (2005:123) dalam (Iqbal 2016) membagi faktor-faktor yang mempengaruhi mendefinisikan Konflik Peran Ganda (Work Family Conflict) menjadi tiga faktor, yaitu:

1. Dalam Diri Individu (General Intra Individual Predictors) Ciri demografis (jenis kelamin, status keluarga, usia anak terkecil) dapat menjadi faktor resiko, kepribadian (seperti negative affectivity, daya tahan, ketelitian) dapat membentengi dari potensi konflik peran. contohnya adalah wanita lebih berpotensi mengalami konflik peran karena tugas-tugas dalam rumah lebih dipandang sebagai tanggung jawab terbesar wanita dari pada laki-laki.

2. Peran Keluarga (Family Role Predictors) Pembagian waktu untuk pekerjaan di keluarga (pengasuhan dan tugas rumah tangga), stresor dari keluarga (dikritik, terbebani oleh anggota keluarga, konflik peran dalam keluarga, ambiguitas peran dalam keluarga).

3. Peran Pekerjaan (Work Role Predictors) Pembagian waktu, terkena stressor kerja (tuntutan pekerjaan atau overload konflik peran kerja, ambiguitas peran kerja, atau ketidakpuasan), karakteristik pekerjaan (kerjasama, rasa aman dalam kerja), dukungan sosial dari atasan dan rekan, karakteristik tempat kerja. Jumlah tugas yang terlalu banyak akan membuat karyawan harus kerja lembur, atau banyaknya tugas keluar kota membuat karyawan akan menghabiskan lebih banyak waktunya untuk pekerjaan dan untuk berada di perjalanan.

Dalam pengertian ini termasuk istri sendiri atau bersama suami berusaha untuk memperoleh penghasilan, dengan demikian wanita yang bekerja dapat dianggap berperan ganda. Secara umum, disesuaikan dengan keadaan social budaya yang 
tumbuh dan berkembang di Indonesia selama ini dapat disimpulkan bahwa ada tiga tugas utama wanita dalam rumah tangga yaitu:

1. Sebagai istri, supaya dapat mendampingi suami sebagai kekasih dan sahabat untuk bersama membimbing keluarga yang bahagia.

2. Sebagai pendidik, untuk pembina generasi muda supaya anak-anak dibekali kekuatan rohani maupun jasmani yang berguna bagi nusa dan bangsa

3. Sebagai ibu rumah tangga, supaya mempunyai tempat aman dan teratur bagi seluruh anggota keluarga.

\section{Stres Kerja}

Mangkunegara (2005) dalam (Sari 2015) menyatakan bahwa stres kerja adalah perasaan yang menekan atau merasa tertekan yang dialami karyawan dalam menghadapi pekerjaan. Stres kerja ini dapat menimbulkan emosi tidak stabil, perasaan tidak tenang, suka menyendiri, sulit tidur, merokok berlebihan, tidak bisa rileks, cemas, tegang, gugup, tekanan darah meningkat dan mengalami gangguan pencernaan.

Sedangkan menurut Robbins (Wahjono, 2010:107) stres menunjukkan suatu kondisi dinamik yang di dalamnya seorang individu menghadapi peluang, kendala, atau tuntutan yang dikaitkan dengan apa yang sangat diinginkan dan yang hasilnya dipersepsikan sebagai tidak pasti tetapi penting. Stres kerja adalah suatu kondisi ketegangan yang menciptakan adanya ketidakseimbangan fisik dan psikis, yang mempengaruhi emosi, proses berpikir dan kondisi seorang pegawai, dalam hal ini tekanan tersebut disebabkan oleh lingkungan pekerjaan tempat pegawai tersebut bekerja. Stres kerja adalah perasaan yang menekan atau merasa tertekan yang dialami pegawai dalam menghadapi pekerjaan (Mangkunegara, 2005:29).

\section{Faktor-faktor Yang Mempengaruhi Stres Kerja}

Menurut Gibson (1987: 207) dalam (Hermita 2011), ada empat faktor penyebab terjadinya stres. Stres terjadi akibat dari adanya tekananan (Stressor) di tempat kerja, stressor tersebut yaitu :

1. Stressor Lingkungan Fisik berupa sinar, kebisingan, temperature dan udara yang kotor.

2. Stressor Individu berupa Konflik peranan, ketaksaan peranan, beban kerja, tanggung jawab terhadap orang lain, ketiadaan kemajuan karir dan rancangan pengembangan karir.

3. Stressor Kelompok berupa hubungan yang buruk dengan rekan sejawat, bawahan dan atasan. Stressor Keorganisasian berupa ketiadaan partisipasi, struktur organisasi, tingkat jabatan, dan ketiadaan kebijaksanaan yang jelas

\section{Pengaruh Konflik Peran Ganda terhadap Kinerja}

Konflik kerja dapat mempengaruhi kinerja karyawan dalam suatu perusahaan. Konflik adalah persaingan yang kurang sehat berdasarkan ambisi dan sikap emosional dalam memperoleh kemenangan yang dapat menimbulkan ketegangan, konfrontasi, pertengkaran, stress dan frustasi apabila masalah mereka tidak dapat diselesaikan. Hal tersebut tentu akan merugikan perusahaan yaitu berupa turunnya kinerja yang diakibatkan adanya stress dan konflik dalam lingkungan kerja. 


\section{Pengaruh Stress Kerja Terhadap Kinerja Pegawai}

Robbins (2006) menyatakan tingkat stress kerja yang mampu dikendalikan mampu membuat pegawai melakukan pekerjaanya dengan lebih baik, karena membuat mereka mampu meningkatkan intensitas kerja, kewaspadaan, dan kemampuan berkreasi, tetapi tingkat stress kerja yang berlebihan membuat kinerja mereka akan mengalami penurunan.

Williams, et al, (2001) dalam Jane Y.Roboth (2015) berpendapat bahwa stress kerja yang tinggi baik fisik maupun perilaku adalah hasil jangka pendek dari job stress kerja yang dapat berpengaruh pada kinerja pegawai yang rendah. Stress kerja pada pegawai bukanlah suatu hal yang selalu berakibat buruk pada pegawai dan kinerjanya, melainkan stress kerja juga dapat memberikan motivasi bagi pegawai untuk memupuk rasa semangat dalam menjalankan setiap pekerjaannya untuk mencapai suatu prestasi kerja yang baik buat karier pegawai dan untuk kemajuan dan keberhasilan perusahaan.

\section{Penelitian Terdahulu}

a. Netemeyer et al (2005) menjelaskan adanya antecendent kunci dan konsekuensi antara konflik peran, kinerja pelayanan pada pelanggan dan stress kerja. Dalam penelitian mereka menyatakan stres kerja karyawan menjadi predictor utama terhadap in role performance supervisor dan extra-role performance karyawan dan pelanggan secara langsung. Sementara konflik pekerjaan-keluarga dan konflik keluarga-pekerjaan menghasilkan stress kerja

b. Price (2003) mengatakan bahwa stress ditempat kerja juga berhubungan positif dengan kinerja karyawan. stress dapat menciptakan keunggulan kompetitif bagi perusahaan dengan manajemen yang baik. Stress juga memberikan dampak positif yang lain seperti dengan adanya batasan waktu perusahaan dapat menjadi lebih efisien dan efektif.

c. Jane Y. Roboth (2015) mengenai analisis work family conflict, stres kerja dan kinerja wanita berperan ganda pada Yayasan Compassion East Indonesia yang menunjukkan bahwa konflik pekerjaan-keluarga berpengaruh tidak signifikan terhadap kinerja wanita berperan ganda.

d. Habibullah Jimad (2010) Pengaruh Konflik Peran Ganda dan Komitmen Organisasi Terhadap Kinerja terdapat Konflik peran ganda dan komitmen organisasi secara simultan berpengaruh terhadap kinerja karyawati perbankan di Bandar Lampung. Konflik peran ganda tidak berpengaruh secara signifikan terhadap kinerja karyawati di Bandar Lampung. Komitmen organisasi memiliki pengaruh yang besar terhadap kinerja.

e. Yavas, Babakus dan Karatepe (2008) Attitudinal And Behavioral Consequences of Work-Family Conflict And Family-Work Conflict: Does Gender Matter? Menyatakan Konflik pekerjaan- keluarga memiliki hubungan positif dan dengan kinerja karena ternyata dapat memicu prestasi kerja karyawan. Sedangkan konflik keluarga-pekerjaan berpengaruh negative dan signifikan terhadap kinerja karyawan.

f. Lutfiyah (2011) mengenai analisis faktor yang mempengaruhi stres kerja pada polisi lalu lintas yang menunjukkan bahwa beban kerja, pengembangan karir dan sub divisi adalah faktor-faktor yang berpengaruh secara signifikan terhadap 
stres kerja pada polisi lalu lintas dengan korelasi yang positif. Oleh sebab itu untuk meningkatkan kinerja polisi.

\section{METODE PENELITIAN}

Metode yang digunakan untuk pengambilan sampel menggunakan teknik penarikan Pusposive Sampling yaitu sampel yang digunakan jika dalam upaya memperoleh data tentang masalah yang diteliti memerlukan sumber data yang memiliki criteria khusus berdasarkan penelitian tertentu (Sugiana,2008). Untuk pengambilan sampel yang digunakan dalam penelitian ini menggunakan syarat syarat sebagai berikut :
a. Polisi wanita
b. Sudah Menikah atau sudah pernah menikah
c. Lama Kerja Minimal 2 Tahun
d. Usia antara $20-55$ tahun

\section{Teknik Pengumpulan Data}

Teknik pengumpulan data yang digunakan untuk membahas masalah dalam penelitian ini adalah:

1. Penelitian Lapangan (field research), yaitu mengumpulkan data dengan cara melakukan penelitian kelapangan berupa :

a. Wawancara adalah dengan melakukan tanya jawab langsung antara peneliti dengan narasumber tentang Polisi Wanita Polresta Padang.

b. Kuesioner adalah pengumpulan data atas jawaban responden berupa pertanyaan atau penyataan yang diajukan oleh peneliti untuk mengetahui keadaan atau kondisi perusahaan tersebut.

c. Observasi adalah pengamatan secara langsung terhadap objek yang akan diteliti pada Polisi Wanita Polresta Padang.

Pada penelitian ini tingkat penelitiannya dengan menggunakan 4 skala Likert, karena peneliti ingin mendapatkan jawaban yang pasti dari penyataan yang disunguhkan dan agar sesuai dengan batasan-batasan yang ingin diperoleh peneliti. Pengukuran skala Likert ini memiliki ketentuan sebagai berikut : Jawaban Skor

- Sangat Setuju (SS) : : 4

- Setuju (S) : 3

- Tidak Setuju (TS) : : 2

- Sangat Tidak Setuju (STS): 1

2. Penelitian kepustakaan (library research) merupakan pengumpulan data yang dilakukan oleh peneliti dengan cara mempelajari literatur, skripsi, dan hasil penelitian orang lain yang berhubungan dengan permasalahan yang dibahas.

Analisis data dalam penelitian ini menggunakan analisis regresi linier berganda, dengan formulasi :

$$
\mathrm{Y}=\mathrm{a}+\mathrm{b}_{1} \mathrm{X}_{1}+\mathrm{b}_{2} \mathrm{X}_{2}+\mathrm{e}
$$

Dimana:

$\mathrm{Y}=$ Kinerja

a $\quad=$ Konstanta

$\mathrm{b}_{1}, \mathrm{~b}_{2}=$ Koefisien regresi 


$$
\begin{array}{ll}
\mathrm{X}_{1} & =\text { Konflik Peran Ganda } \\
\mathrm{X}_{2} & =\text { Stres Kerja } \\
\mathrm{e} & =\text { error/ kesalahan }
\end{array}
$$

\section{PEMBAHASAN}

\section{Pengaruh Konflik Peran Ganda Terhadap Kinerja Polisi Wanita}

Berdasarkan hasil analisis, diperoleh nilai koefisien determinasi (R2) sebesar 0,070 atau $70 \%$, artinya bahwa variabel kinerja polisi wanita dapat dijelaskan oleh faktor konflik peran ganda dan stres kerja sebesar 70\%, sedangkan sisanya yaitu $30 \%$ dijelaskan oleh faktor yang lain diluar model penelitian ini. Hasil uji t untuk konflik peran ganda (X1) terhadap kinerja $(Y)$ hy menunjukkan nilai 0,811 , artinya nilai sig lebih besar dari nilai probabilitas $0,05(0,420>0,05)$ dan $t$ hitung lebih kecil dari $t$ table $(0,811<2,000)$, maka kesimpulan yang dapat diambil adalah $\mathrm{H} 01$ diterima dan H1 ditolak. Ini berarti konflik peran ganda tidak berpengaruh signifikan terhadap kinerja Polisi wanita di Polresta Padang, Untuk uji F Berdasarkan hasil pengolahan data dapat dilihat bahwa nilai signifikasi $\mathrm{F}$ hasil pengujian sebesar 0,042 seperti yang dikemukakan pada tabel 4.13. Hal ini berarti signifikasi $F$ lebih kecil dari 0,05. Hal ini menunjukkan ada pengaruh yang positif dan signifikan secara simultan/serempak antara konflik peran ganda dan stres kerja terhadap kinerja polisi wanita Polresta Padang.

Hasil penelitian menunjukkan bahwa hipotesis pertama ditolak, karena konflik peran ganda tidak berpengaruh signifikan terhadap kinerja polisi wanita di Polresta Padang. Hal ini berarti bahwa polisi wanita berperan ganda di Polresta Padang sudah dapat mengatasi konfik peran ganda secara profesional sehingga tidak mempengaruhi hasil kinerjanya. Walaupun dengan tugas, kewajiban dan beban kerja yang berat polisi wanita Polresta Padang sudah dapat meminimalisasi kemungkinan adanya benturan dan tekanan dalam pekerjaan atau keluarga. Sehingga kewajiban sebagai ibu rumah tangga dan tuntutan sebagai wanita karir dapat berjalan dengan seimbang. Hal ini sejalan dengan penelitian terdahulu Jane Y. Roboth (2015) mengenai analisis work family conflict, stres kerja dan kinerja wanita berperan ganda pada Yayasan Compassion East Indonesia yang menunjukkan bahwa konflik pekerjaan-keluarga berpengaruh tidak signifikan terhadap kinerja wanita berperan ganda, Habibullah Jimad (2010) dan Maherani (2008) yang menunjukkan bahwa konflik peran ganda tidak memiliki pengaruh yang signifikan terhadap kinerja..

\section{Pengaruh Stress kerja Terhadap Kinerja Polisi Wanita}

Hasil uji t untuk Stres ketja (X2) terhadap kinerja (Y) menunjukkan nilai sig 0,049 dan t hitung menunjukkan nilai 2,008, artinya nilai sig lebih kecil dari nilai probabilitas $0,05(0,049<0,05)$ dan thitung lebih besar dari t tabel $(2,008>2,000)$, maka kesimpulan yang dapat diambil adalah $\mathrm{H} 02$ ditolak dan $\mathrm{H} 2$ diterima. Ini berarti Stres kerja berpengaruh signifikan positif terhadap kinerja Polisi Wanita di Polresta Padang.

Hipotesis kedua diterima, karena stres kerja berpengaruh positif dan signifikan terhadap kinerja polisi wanita di Polresta Padang. Artinya dengan tugas, peran dan tanggung jawab yang harus dipenuhi oleh seorang polisi wanita, terkadang setiap individu mengalami stres kerja karena beban yang terlalu berat. Stres kerja dapat 
berasal dari individu, lingkungan ataupun organisasi. Akan tetapi stres kerja yang dialami oleh polisi wanita disini justru bersifat positif yang menimbulkan dorongan atau motivasi untuk menampilkan perfoma kinerja yang baik. Hal ini sesuai dengan Teori, Price (2003) mengatakan bahwa stress ditempat kerja juga berhubungan positif dengan kinerja karyawan. stress dapat menciptakan keunggulan kompetitif bagi perusahaan dengan manajemen yang baik. Stress juga memberikan dampak positif yang lain seperti dengan adanya batasan waktu perusahaan dapat menjadi lebih efisien dan efektif. Dan diperkuat dengan penelitian terdahulu Lutfiyah (2011) mengenai analisis faktor yang mempengaruhi stres kerja pada polisi lalu lintas yang menunjukkan bahwa beban kerja, pengembangan karir dan sub divisi adalah faktorfaktor yang berpengaruh secara signifikan terhadap stres kerja pada polisi lalu lintas dengan korelasi yang positif. Oleh sebab itu untuk meningkatkan kinerja polisi.

\section{PENUTUP}

\section{Kesimpulan}

1. Hasil uji t untuk konflik peran ganda (X1) terhadap kinerja (Y) menunjukkan nilai sig 0.420 dan t hitung menunjukkan nilai 0,811 , artinya nilai sig lebih besar dari nilai probabilitas $0,05(0,420>0,05)$ dan $\mathrm{t}$ hitung lebih kecil dari $\mathrm{t}$ table $(0,811<2,000)$, maka kesimpulan yang dapat diambil adalah H01 diterima dan $\mathrm{H} 1$ ditolak. Ini berarti konflik peran ganda tidak berpengaruh signifikan terhadap kinerja Polisi wanita di Polresta Padang.

2. Hasil uji t untuk Stres ketja (X2) terhadap kinerja (Y) menunjukkan nilai sig 0,049 dan t hitung menunjukkan nilai 2,008, artinya nilai sig lebih kecil dari nilai probabilitas $0,05(0,049<0,05)$ dan $t$ hitung lebih besar dari t tabel $(2,008>2,000)$, maka kesimpulan yang dapat diambil adalah H02 ditolak dan $\mathrm{H} 2$ diterima. Ini Stres kerja berpengaruh signifikan positif terhadap kinerja Polisi Wanita di Polresta Padang.

3. Koefisien determinasi menunjukkan bahwa konflik peran ganda, dan stres kerja secara keseluruhan mampu menjelaskan kinerja polisi wanita Polresta Padang sebesar $70 \%$ (0,070 x 100\%), sedangkan sebesar 30\%, (100\%-70\%) Kinerja Polisi dijelaskan oleh variabel lain yang tidak diteliti.

\section{Saran}

1. Bagi pihak kepolisian, diharapkan lebih memperhatikan stress kerja walaupun pada penelitian ini stress kerja berpengaruh positif tetapi perlu perhatian juga karena ketika polwan mempunyai stress kerja yang terus menerus maka pada akhirnya akan berdampak negative yang akibatnya menurunkan kinerja karyawati polwan di Polresta Padang, Sehingga perlu menciptakan kondisi kerja dimana polwan di Polresta Padang dapat nyaman melakukan tugasnya.

2. Untuk penelitian selanjutnya, diharapkan penelitian ini dapat ditambah variabel variabel independennya karena masih banyak faktor yang mempengaruhinya. Diharapkan dalam melakukan penelitian yang sama, variabel stress kerja lebih dispesifikan lagi karena agar lebih detail seperti stress individu, stress organisasi dan stress lingkungan kerja yang mempengaruhi positif atau negatif . Diharapkan sampel yang digunakan lebih 
diperbanyak karena semakin banyak sampel yang digunakan menunjukkan tingkat keakurasian data dalam menjawab fenomena yang terjadi.

\section{DAFTAR PUSTAKA}

Adam, alfan. 2013. "Pengaruh Kedisiplinan Terhadap Kinerja Anggota Kepolisian Pada Resort Kutai Kartanegara." Fakultas isipol jurusan ilmu adm.negara universitas 17 agustus 1945 samarinda. Kalimantan timur: 48-55.

Dona, E. (2016). Pengaruh Perencanaan, Prosedur Dan Pengawasan dan Komitmen Organisasi Dalam Pelaksanaan Anggaran Terhadap Kinerja Pegawai Dinas Pekerjaan Umum Kota Pariaman. Jurnal Riset Manajemen dan Akuntansi (Jurmak), 23-35

Dona, E. (2018). Analisis Motivasi Kerja Ditinjau Dari Lingkungan Kerja Kasus Karyawan LBPP Lia Payakumbuh. Jurnal KBP.

Evy Siska Yuliana, Reny Yuniasanti. 2013. “ Hubungan Antara konflik pekerjaankeluarga dengan kepuasan kerja pada polisi wanita di polres kulon progo." Fakultas psikologi universitas mercu buana yogyakarta abstract 4(5): 62-73.

Ginanjar, Rodi Ahmad. 2013. "Pengaruh lingkungan kerja terhadap kinerja karyawan pada dinas pemuda dan olahraga kabupaten sleman." Universitas negeri yogyakarta: $1-140$.

Hermita. 2011. "Pengaruh stres kerja terhadap kinerja karyawan pada PT. Semen Tonasa (Persero) pangkep." Universitas hasanuddin makassar.

Iqbal Muhammad. 2016. "Pengaruh

Konflik Peran ganda dan stres kerja terhadap kinerja pegawai wanita pada rumah sakit umum daerah menggala." Program pascasarjana magister manajemen fakultas ekonomi dan bisnis universitas lampung bandar lampung.

Junaidi, R., \& Susanti, F. (2019). Pengaruh Gaya Kepemimpinan Dan Budaya Organisasi Terhadap Kinerja Pegawai Pada UPTD Baltekkomdik Dinas Pendidikan Provinsi Sumatera Barat. https://doi.org/10.31227/osf.io/bzq75

Lubis, A. Y. O., \& Susanti, F. (2019). Pengaruh Gaya Kepemimpinan Dan Kompensasi Terhadap Prestasi Kerja Karyawan (Studi pada PT Japfa Comfeed Indonesia (JCI) Tbk Devisi Fam 1. https://doi.org/10.31227/osf.io/7tbrg

Mayliza, R. (2019). Pengaruh Konflik Dan Kejenuhan Terhadap Kepuasan Kerja Karyawan PT. PLN (Persero) Sektor Pembangkitan Dan Pengendalian Pembangkitan Ombilin. https://doi.org/10.17605/OSF.IO/DQZ3K

Mayliza, R. (2019). Kontribusi Sistem Penghargaan Dan Lingkungan Kerja Terhadap Efektifitas Kerja Pegawai Pada Kantor Dinas Pendidikan Kota Padang. https://doi.org/10.17605/OSF.IO/VWZH3

Mayliza, R. (2019). Pengaruh Gaya Kepemimpinan Dan Disiplin Kerja Terhadap Kinerja Pegawai, Dengan Motivasi Kerja Sebagai Variabel Intervening (Studi Pada Dinas Pendidikan Kabupaten Tanah Datar). https://doi.org/10.17605/OSF.IO/JGPDN

Nardo, R. Evanita, Syahrizal, S. (2018). Pengaruh Kepemimpinan Transformasional, Dan Lingkungan Kerja Non Fisik Terhadap Perilaku Inovatif. JEBI (Jurnal Ekonomi dan Bisnis Islam) 3 (2), 209-215

Nardo, R. Evanita, Syahrizal, S. (2019). The Effect of Transformational Leadership 
and Non Physical Work Environment on Innovative Behavior with Work Motivation as a Mediation For Employees of Tour And Travel Companies In West Sumatera. 2nd Padang International Conference on Education, Economics, Business and Accounting (PICEEBA-2 2018)

Putra, RY. Marlius, D. (2019). Pengaruh Pendidikan, Pengalaman Kerja dan Etos Kerja Terhadap Kinerja Pegawai Di KPN Batur. Academic Conference For Management 2.

Rahmizal, M. (2018). Pengaruh Pendapatan, Pendidikan, Kesehatan, Modal Sosial Dan Religiusitas Terhadap Kebahagiaan Individu Di Indonesia. Universitas Gadjah Mada

Ratna kartika, nasir azis, amri. 2014. "Pengaruh konflik peran ganda dan stres kerja terhadap kinerja pemeriksa bpk ri perwakilan provinsi aceh." Magister manajemen program pasca sarjana universitas syiah kuala banda aceh,

Ridho, M., \& Susanti, F. (2019). Pengaruh Stres Kerja Dan Motivasi Kerja Terhadap Kepuasan Kerja Pada Karyawan Bank Mandiri Syariah Cabang Padang. https://doi.org/10.31227/osf.io/pa2cg

Ririn Wedya Putri Mayang Sari, Ahmad mardalis, se, mba. 2015. "Pengaruh Konflik Peran Ganda dan Stres Kerja Terhadap Kinerja Polisi Wanita Di Polresta Surakarta.

Sari, Ria Puspita. 2015. "Pengaruh Stres Kerja dan Konflik Kerja terhadap Kinerja Karyawan Jambuluwuk Malioboro Boutique Hotel Yogyakarta." Jurnal studi manajemen organisasi 11(1): 1-6.

Silalahi, hotmaida elfrida. 2015. "Pengaruh Konflik Peran Ganda Terhadap Produktivitas Karyawati yang berkeluarga pada PT. Sarimakmur Tunggal Mandiri Medan." Fakultas psikologi, universitas hkbp nommensen,medan.

Susriyanti, S. Nardo, R. (2019). Pengaruh Fungsi Komunikasi Dan Kepuasan Kerja Karyawan Terhadap Pemberian Pelayanan Nasabah PT. BPR LPN Talawi Sakato. Jurnal Administrasi Sosial dan Humaniora 3 (2), 97-111.

Sutanto, veliana et al. 2016. "Analisa Pengaruh Work Family Conflict Terhadap Stres Kerja dan Kinerja Karyawan di Restoran The Duck King Imperial Chef Galaxy Mall Surabaya." Program manajemen perhotelan, fakultas ekonomi, universitas kristen petra: 377-91.

Wirakristama, Richardus Chandra. 2011. “Analisis Pengaruh Konflik Peran Ganda (work family conflict) terhadap Kinerja Karyawan Wanita Fakultas ekonomi universitas diponegoro (december 2011). 